\title{
Tierra del Fuego and Isla de los Estados Peatlands
}

\section{Adolfina Savoretti, Juan Federico Ponce, Claudio Roig and Andrea Coronato}

\begin{abstract}
This chapter highlights different aspects of origin, vegetation development and uses of Tierra del Fuego and Isla de los Estados peatlands. Most peatlands in the region were formed when the Last Glaciation was ending, during the Late Glacial period (between 19,000 and 11,500 years BP), while the active glaciers were receding. In peatlands, plant communities vary their composition along the time related to climatic and hydrological changes taking place during its formation. These changes are recorded in the succession of plant macro-remains preserved in-situ. According to the dominant species, peatlands of Tierra del Fuego may be classified in three main types: Sphagnum or raised bogs, Astelia or cushion bogs and Carex or sedge fens. Uses of peat deposits are made principally on Sphagnum magellanicum bogs base on its particular properties. Different uses of the peat material can be mentioned: fuel, solid base for leguminosae inoculants, industrial absorbents for oil and hydrocarbons, orchid intensive culture, mushroom casing, aquariums and biofertilizers.
\end{abstract}

\section{Introduction}

Peatlands are wetlands in which the organic matter production is higher than its decomposition (Clymo 1984). As a result, considerable amounts of organic matter accumulate along thousands of years (Vitt and Wieder 2009). This organic matter is mainly formed by remaining fragments of partial decomposition of those plants which once lived on the peatland surface (Vitt and Wieder 2009). Several factors have an influence on its origin and preservation, such as a positive humidity balance (lower evaporation than precipitation), high relative humidity, geological and topographic conditions that favor water retention, low substrate $\mathrm{pH}$ and nutrients availability (Clymo 1984). Water saturation leads to a low oxygen content which added to low temperatures along the year inhibit microorganism's activity (fungi and bacteria) which produce the decomposition of dead vegetal matter. This is the way in which vegetal matter is 
decomposed at a lower rate than it is produced, allowing the accumulation of peat (Rydin and Jeglum 2006).

Peatlands are formed by two main layers: the upper one, aerobic, called acrotelm and a lower one, anaerobic, the catotelm (Vitt and Wieder 2009). The vascular plants (herbs, shrubs and trees) produce less biomass and decompose faster than the bryophytes (mosses and liverworts) which are dominant at the soil layer (Vitt and Wieder 2009). The surfaces of peatlands are covered by a continuous moss surface and most of the biomass occurring in this layer is represented by the material of the cell walls which decompose more slowly. According to studies carried out in Canada accumulated peat is material from bryophytes in a high percentage (Janssens 1990; Vitt and Wieder 2009).

As mentioned above, geological and geomorphologic conditions have an influence in the development of these ecosystems (Coronato et al., 2006). A peatland formation is favored by the occurrence of basins or closed depressions where small lakes or ponds are formed. This type of landscape is mainly associated to areas which have been previously exposed to erosive glacial action, such as the basin of glacial valleys (Ponce et al. 2014). The glacier erosive task over the rock or sediment along which it flowed originated this kind of basins or depressions. Other types of depressions may be formed between glacial or glaciofluvial sediment accumulation landforms under or near the front of the glacier. Later, when the glacier retreated and left such depressions free, the small basins were flooded, either due to surface water runoff from the side slopes or to the occurrence of high phreatic water, giving birth to lakes and ponds (Figs. 1a, b). Later, the lowering of the depth of these freshwater bodies, together with the growth of vegetation associated to waterlogging areas, produced a gradual advance and colonization by the vegetation over the water body, thus forming the peatlands (Ponce et al. 2014, Figs. 1c, d).

Changes given to its drainage conditions may arise variations in the type of vegetation, leading to forming more than one type of peat material within the same peatland (Fig. 1e). Peatlands may also occur near streams and rivers, on the flooding plains and abandoned meanders. In the first three cases, which are flat, inefficient drainage conditions favor the waterlogging of large areas, thus allowing the growth of typical peatland vegetation; whereas in the latter, aquatic plant species start living within the 
residual waterlogging areas, starting the process of colonization and plant succession (Ponce et al. 2014).

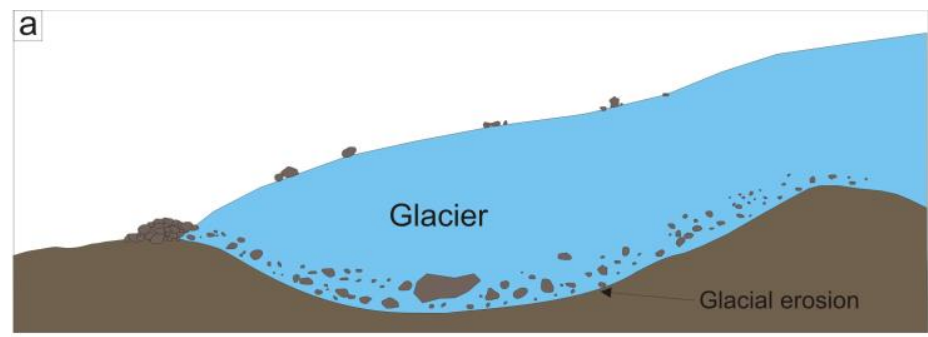

$\mathrm{b}$

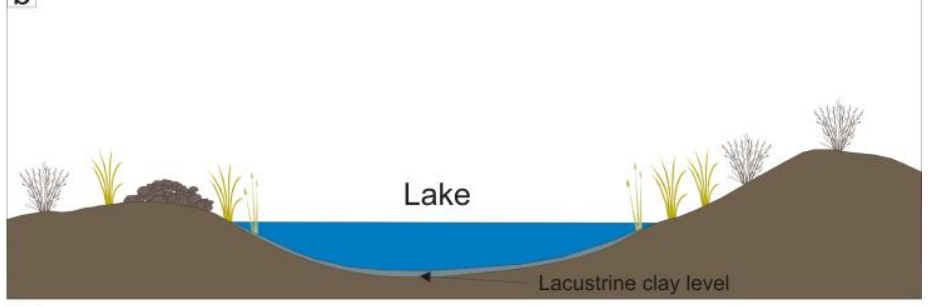

C

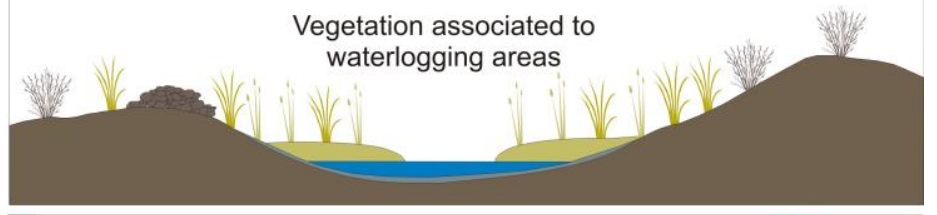

d

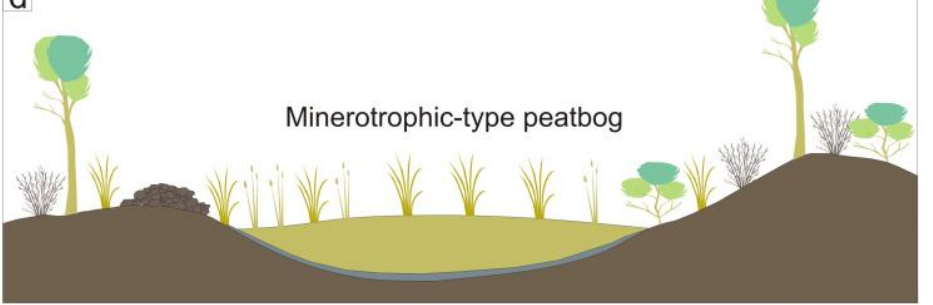

e

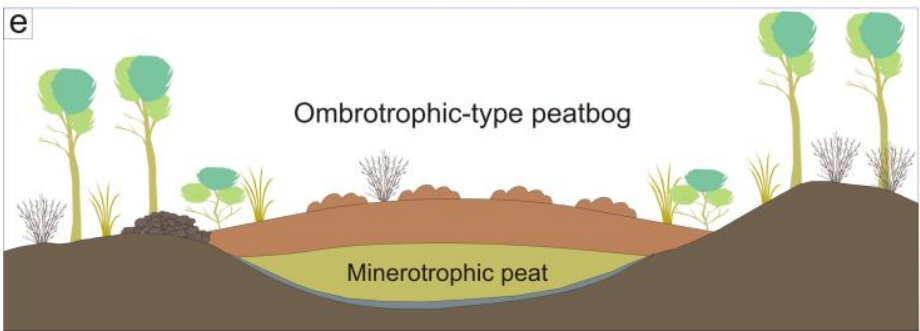

Fig. 1 Peatbog formation and evolution in the southern section of Isla Grande de Tierra del Fuego (modified from Ponce et al. 2014).

\section{Previous works about peatlands classification in Tierra del Fuego}

Among the several authors who produced valuable information about the peatlands of Tierra del Fuego Bonarelli's work (1917) must be highlighted. He carried out several 
classifications of peatlands in Tierra del Fuego, mainly based on different environments of origin, flora, peculiarities of the subsoil, chemical composition and climatic factors.

Some decades later, Roivainen (1954) made an important contribution when defining precisely the plant communities typical of the different types and subtypes of peatlands in Tierra del Fuego. He summarizes the spatial distribution according to three regional types: 1 . Sedge mires, 2. Sphagnum-bushy peatbogs and 3. Rain peatbogs.

Auer (1965) interpreted the regional distribution of peatlands in Tierra del Fuego separately from the rest of Patagonia, pointing out the transition of the "Fuegian" peatlands from the mountain environment in the southwest to the seashore to the northeast. He made out profiles in several peatbogs which show the variations on their thickness. Based on types of vegetation, latitude, altitude and environmental conditions, he defined six categories according to a latitude distribution, from north to south: steppe, transitional, Sphagnum, transitional and rainy-area regional peatlands.

Pisano (1977) classified peatlands in three categories with several subtypes:

(a) Raised peatlands: including communities from the Magellanic tundra dominated by up-raised cushion bryophytes, over the general surface and over the secondary water table.

(b) Pulvinated peatlands: including not-raised peatlands over the "mineralized" phreatic water which overlays the landscape. They are found in areas with higher rainfall than the raised peatlands.

(c) Graminoid peatlands: are those dominated by graminoid types, where these plants represent over $50 \%$.

In his detailed floristic work, Moore (1983), described the peatlands developed in each vegetation unit of Isla Grande de Tierra del Fuego:

1. Deciduous Forest:

- Sphagnum bog: communities dominated by Sphagnum magellanicum, co-dominanted by Empetrum rubrum, with different species of Carex, Gunnera magellanica, Marsippospermum grandiflorum, Perezia lactucoides, Gaultheria pumila, Tetroncium magellanicum. 
- Marsippospermum bog: Marsippospermum grandiflorum is the dominant species, and cushion mosses, principally Sphagnum and liverworts are important components.

2. Evergreen Forest:

○ Sphagnum bog: Sphagnum associations are similar to those described above, but there are also present Donatia fascicularis, Oreobolus obtusangulus, Schoenus andinus, Senecio trifurcatus and Pilgerodendron uviferum.

3. Magellanic Moorland:

- Cushion bog: Astelia pumila, Bolax caespitosa, Caltha dioneifolia, Donatia fascicularis, Drapetes muscosus, Gaimardia australis, Phyllachne uliginosa are the most important cushion species.

○ Graminoid bog: Schoenus antarticus, Tetroncium magellanicum and Carex kingii are the dominant components, commonly associated with eh cushion bog species listed above.

Roig (2000) presented a classification of the peat-producing vegetation communities of Tierra del Fuego aiming at defining those plant communities which are peat deposits producers. They may be summarized in the following: "praderas turbosas" (peaty grasslands), "vegas or mallines" and peatlands.

Finally, Amigo et al. (2017) reviewed and clarified the nomenclature of peatlands from Valdivian-Magellanian area based on plant-sociology data, defining four groups: (a) cushion bogs, (b) Sphagnum bogs, (c) "montane tundra" bogs and, (d) sedge-grass bogs.

\section{Peatlands at Isla de los Estados}

There are extensive peatlands in Isla de los Estados. There are mainly three types to be included in Zone 5 within Auer (1965) classification:

1. Sedge fens, with Cyperaceae, Juncaceae and other associated species such as Astelia pumila, Drosera uniflora, Empetrum rubrum, lichens and ferns (Niekisch and Schiavini 1998, unpublished). 
2. Sphagnum-dominated bogs, where the peatmoss forms cushions accompanied by Cyperaceae, Juncaceae and Droseraceae (Drosera uniflora). It presents similar features to those of the peat deposits prevailing in the Isla Grande de Tierra del Fuego (Kühnemann 1976).

3. Astelia pumila-dominated bogs, where Caltha appendiculata, $C$. dioneifolia, Marsippospermum grandiflorum and Empetrum rubrum occur as secondary elements. This type of bog is found in the eastern section of the Isla Grande de Tierra del Fuego (Roig 1998).

\section{Origin and main features of Tierra del Fuego peatlands}

Tierra del Fuego concentrates over 95\% of the total area of peatlands within Argentina (Rabassa et al. 1996), spread basically along the bottom of valleys in the southern region of Isla Grande (Fig. 2). The average thickness of peatlands in Tierra del Fuego is around 4 meters, but some are over 11 meters deep fully containing deposits of organic matter (Ponce et al. 2014).

Most peatlands in the region were formed when the Last Glaciation was ending, during the Late Glacial period (between 19,000 and 11,500 years BP), while the active glaciers were receding. All along this last cold event, the Archipelago of Tierra del Fuego was covered by glaciers to a large extent (Rabassa et al. 2000). In the Main Island almost 50 $\%$ of the area (about 22,500 sq.km) was covered by ice during the last Ice Age. In Isla de los Estados the ice cover would have been almost complete (Ponce and Rabassa 2012). All along the Beagle Channel, Lake Fagnano and Lasifashaj valley were taken up by some of the most extensive of the archipelago (Rabassa et al. 2000). When the last Ice Age was finishing the valleys formerly occupied by glaciers were partly taken up by lakes and large rivers. Later on, changes in the drainage of the basins and a milder climate allowed the vegetation to colonize shallow-pond basins as well as peatlands to occur at the bottom of the former glacial valleys (Ponce et al. 2014).

The oldest record of a peatland in the argentine section of Isla Grande is found in Estancia Harberton, $55 \mathrm{~km}$ east of Ushuaia city, on the northern coast of the Beagle Channel. This bog threw an age of around 20,000 years and a depth of 11 meters (Savoretti 2018). The oldest peatland found so far in Isla de los Estados is in Bahía Colnnet, on the northern coast, which is 16,000 years old and about 8 meters deep. 


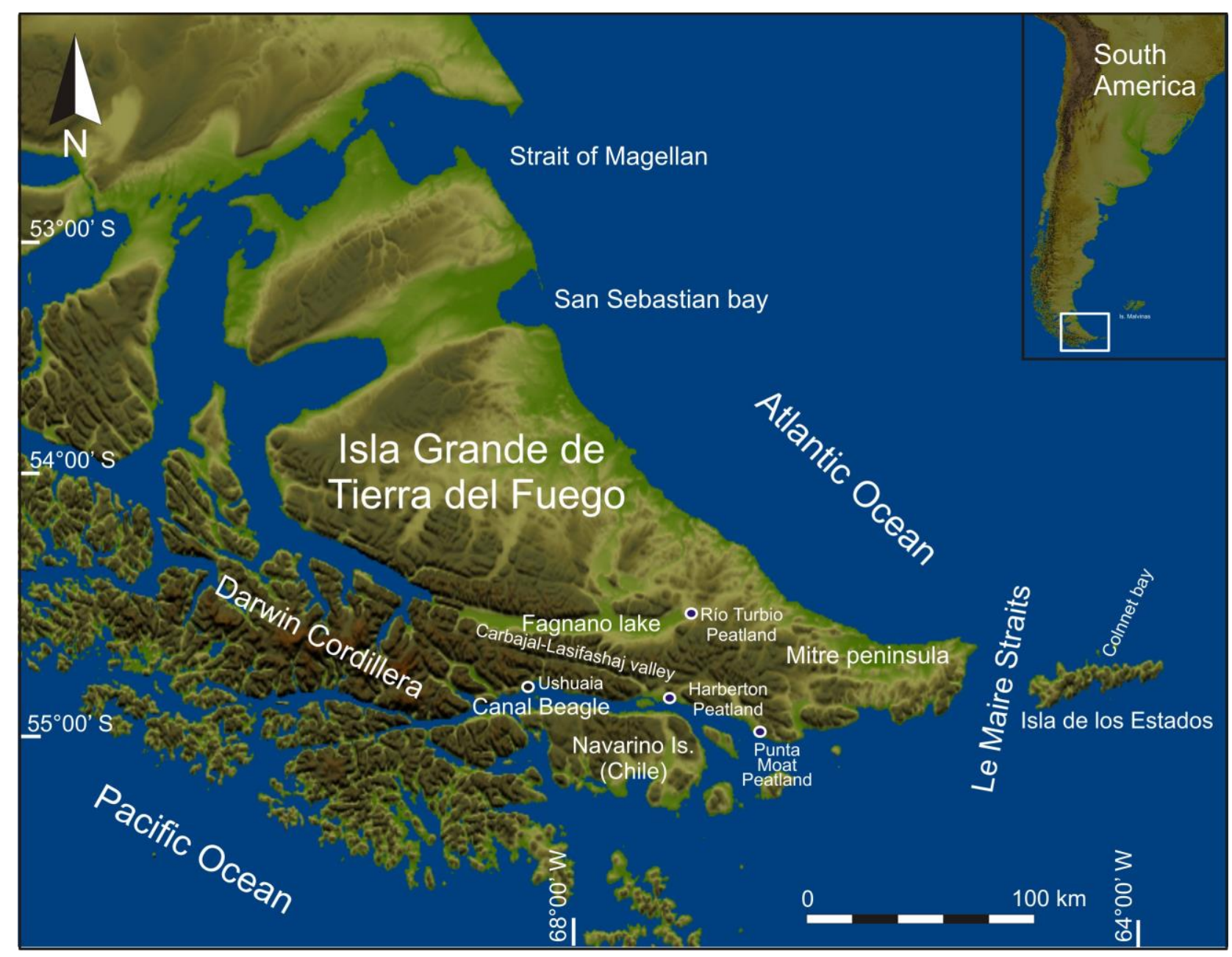

Fig. 2 Tierra del Fuego and Isla de los Estados location map.

\section{Plant composition}

As seen in the different classifications of peatlands of Tierra del Fuego, the plants occurring depend on each type. Besides, these plant communities vary their composition along the time related to climatic and hydrological changes taking place during the Quaternary. These changes are recorded in the succession of plant macro-remains preserved within peatlands (e.g., Mauquoy et al. 2004; Mauquoy and van Geel, 2007; Van der Putten et al. 2012; Echeverría 2016; Savoretti 2018). Macro-remains are those plant fragments which are recognizable at first sight and are 0.5 to $2 \mathrm{~mm}$ in average (Dickson 1986; Birks 2017; Mauquoy et al. 2010). The study of these remains in peatcores allows to find out changes in the plant composition that forms peatlands along the time, make paleoenvironmental reconstructions and paleoclimate inferences. 
The present plant vegetation of the most abundant three types of Tierra del Fuego peatlands (Carex, Sphagnum and Astelia) are here presented as examples. Raised Sphagnum magellanicum bogs are widely distributed in the southern section of Isla Grande, Astelia pumila cushion bogs are common along the coast of Mitre Peninsula and in a wide range in Isla de los Estados, and Carex or sedge fens growing mainly in the northern section of Isla Grande.

Then the past plant composition is described qualitatively through the macro-remains that make the Sphagnum bog.

\section{Harberton bog}

It is located on the northern coast of the Beagle Channel, surrounded by the Nothofagus betuloides - N. pumilio forest. It is an ombrotrophic-raised bog dominated by Sphagnum magellanicum (Fig 2, 3). This peatland is within an inter-drumlin depression, in a drumlin field (Rabassa et al. 1990). It has an area of about $0.5 \mathrm{~km}^{2}$ (Loisel and Yu 2013).

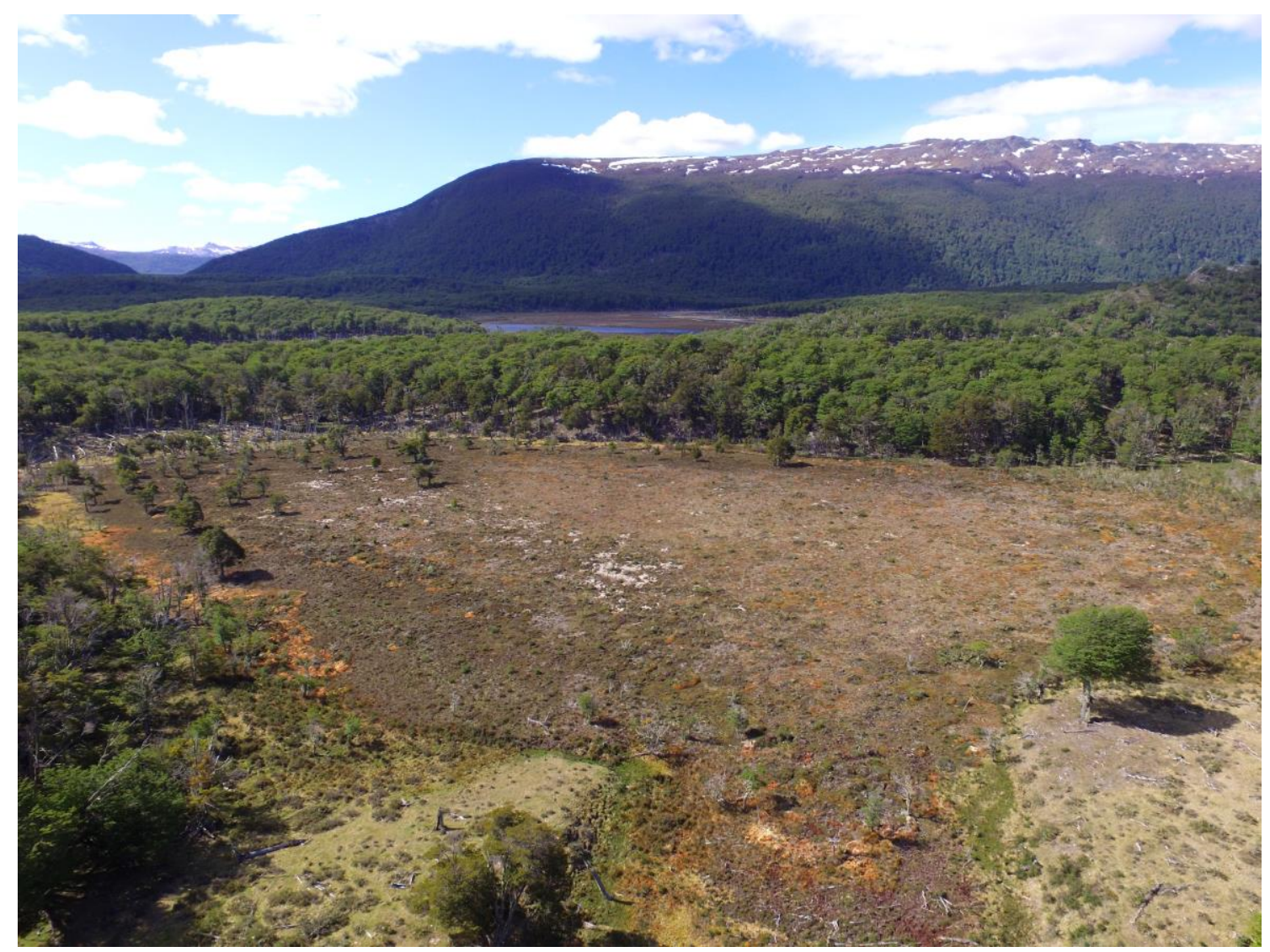


Fig. 3 Aerial view of Harberton bog located on the northern coast of the Beagle Channel. It is an ombrotrophic-raised bog dominated by Sphagnum magellanicum.

The present vegetation is represented by:

Vascular plants: Empetrum rubrum, Nothofagus antarctica, Carex magellanica, Rostkovia magellanica, Gaultheria pumila, Marsippospermum grandiflorum, Caltha appendiculata, Drapetes muscosus, Nanodea muscosa, Tetroncium magellanicum, Avenella flexuosa, Carex sp., Deyeuxia poaeoides, Luzula alopecurus, Juncus scheuchzerioides (Roig et al. 2004).

Bryophytes (mosses and liverworts): Sphagnum magellanicum, Metzgeriales, Polytrichum juniperinum, Sphagnum fimbriatum, Racomitrium geronticum, Bryum pallens, Orthodontium linneare, Pohlia nutans, Campylopus sp., Dicranoloma imponens, Dicranoloma robustum, Amblystegiaceae, Noteroclada confluens (Roig et al. 2004; Savoretti 2018).

Lichens: Cladina sp., Cornicularia aculeata, Cladonia cornuta, Sticta sp., Parmelia sp. (Roig et al. 2004).

\section{Moat bog}

It is a cushion bog dominated by Donatia fascicularis cushions and Astelia pumila grasses, showing an irregular micro-topography with abundant freshwater ponds (Pisano, 1977). The peatland covers an area of 1,7 sq. $\mathrm{Km}$ and it is located east of Moat river, less than $1 \mathrm{~km}$ away from the coast of the Beagle Channel. It is surrounded by the Magellanic evergreen forest represented by Nothofagus betuloides and Drimys winteri (Heusser 1995; Borromei et al. 2014) (Fig 2, 4). 


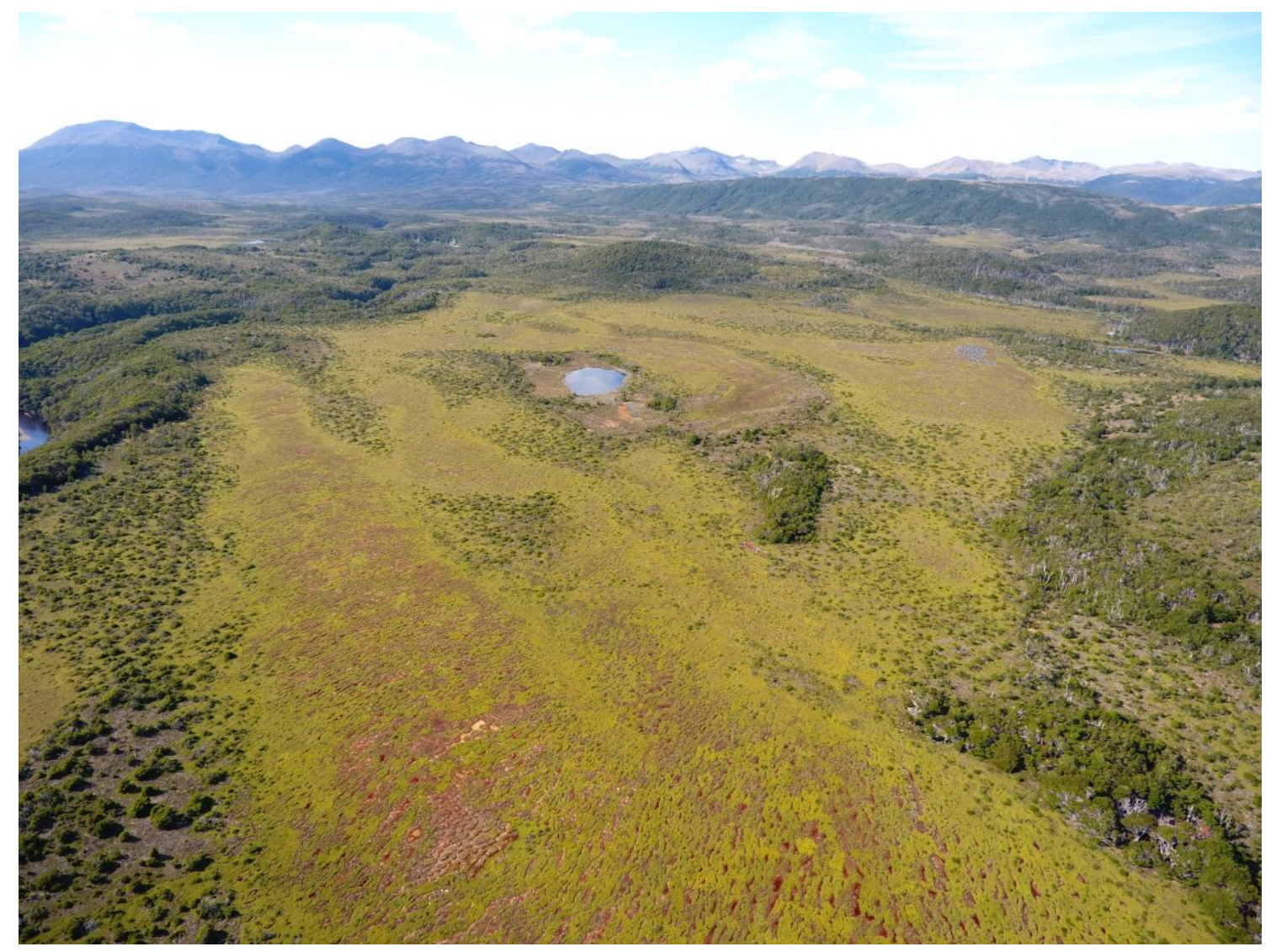

Fig. 4 Aerial view of Moat bog located in easternmost Beagle Channel. It is a cushion bog mostly made of Donatia fascicularis cushions and Astelia pumila grasses.

The present vegetation is represented by:

Vascular plants: Caltha dioneifolia, Drapetes muscosus, Tetroncium magellanicum, Schoenus antarcticus, Gaimardia australis, Uncinia kingii, Acaena pumila, Drosera uniflora, Gaultheria antarctica, Gunnera lobata, Marsippospermum grandiflorum, Myrteola nummularia, Nanodea muscosa, Perezia magellanica, Gaultheria pumila, Tapeinia pumila, Tribeles australis, Berberis ilicifolia, Chiliotrichium diffusum, Embotrhium coccineum, Empetrum rubrum, Escallonia serrata, Philesia magellanica (Moore 1983; Borromei et al. 2014).

Bryophytes (mosses and liverworts): Sphagnum falcatulum, S. magellanicum, Dicranoloma billiardieri, D. chilense, D. imponens, D. robustum, Campylopus sp., Bryum pallens, Pohlia nutans, Lejeunea sp. and Metzgeriales (Savoretti 2018).

\section{Río Turbio fen}

It is a minerotrophic-type peatland (fen) dominated by the family Cyperaceae and different mosses species of the family Amblystegiaceae (called Carex curta flooded 
peatbog by Roig et al. 2004). It is located east of Lake Fagnano, in the central area of the Isla Grande, surrounded by Nothofagus antarctica forest (Fig 2, 5).

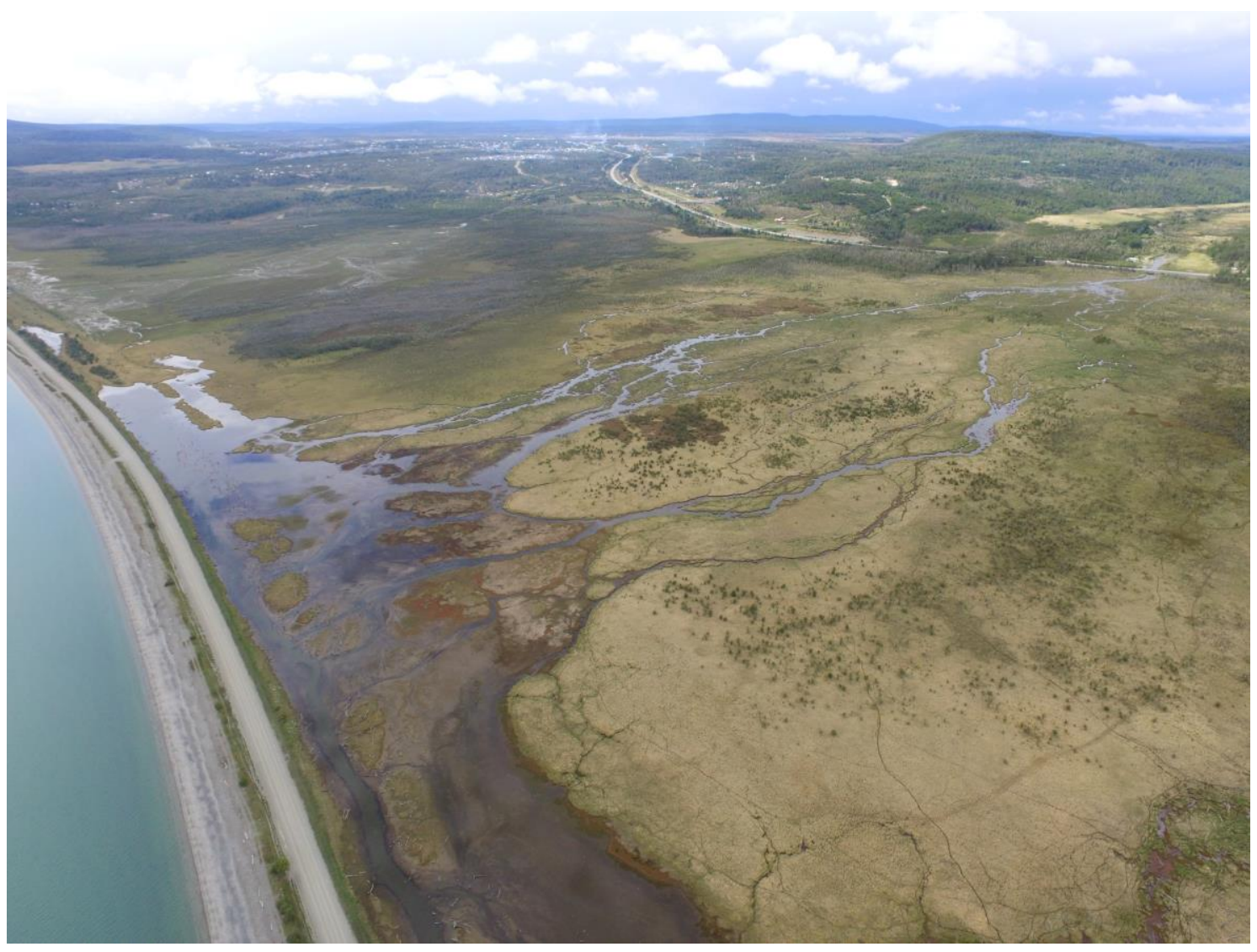

Fig. 5 Aerial view of Río Turbio fen located at east of Fagnano Lake. Minerotrophictype peatland dominated by the family Cyperaceae.

The present vegetation is represented by:

Vascular plants: Carex canescens, Alopecurus magellanicus, Agrostis meyenii, Festuca contracta, Carex magellanica and Nothofagus antarctica (Roig et al. 2004).

Bryophytes (mosses and liverworts): Scorpidium revolvens, Sanionia uncinata, Sphagnum frimbriatum, S. magellanicum, Breutelia integrifolia, Brachythecium sp., Bryum laevigatum, Bryum pallens, Dicranella sp., Distichium sp., Syntrichia robusta, Marchantia sp. (Savoretti 2018).

Changes in the composition of the peat forming vegetation along the time: the case of Harberton bog 
A general characterization of the plant composition in depth of a Sphagnum magellanicum bog is presented and a paleoenvironmental reconstruction for the last 19000 years Cal. BP it is also mentioned (Fig 6). This is the most mined type of peatland in Tierra del Fuego. The description of plant macro-remains composition was made out of a $1035 \mathrm{~cm}$ long peat core taken from Harberton bog. Vegetative zones and sub-zones were defined base on the exhaustive examination of macro-remains. Each delimitated zone represents a particular plant association, allowing a local paleoenvironmental reconstruction (modified from Savoretti, 2018, see methodology therein):

\section{-Zone HB-A (1035-550 cm)}

The sedimentary features in the tract $1035-550 \mathrm{~cm}$ vary from gytjja to dark brown peat very humified to humified, quite compacted. The content of plant macro-remains is dominated by herbaceous and Bryopsida (non-sphagnaceous mosses). Sphagnum magellanicum is found in low concentrations compared to Zone B.

\section{-Zone HB-A1 $(1035-850 \mathrm{~cm})$}

In this subzone 8 bryophyte taxon are recognized, the most diverse subzone of the group. Among the best represented taxons are the mosses Isopterygiopsis sp., Plagiothecium sp. and Scorpidium revolvens. The vascular plants are found in high concentrations, the herbaceous plants being the most abundant; another important component are the Ericaceae seeds.

-Subzone HB-A2 (850-550 cm)

The vascular plants are dominant in this subzone, mostly represented by the herbaceous. Besides, Sphagnum magellanicum macro-remains were found in a similar rate as Bryopsida. Scorpidium revolvens is represented in a lower rate.

\section{-Zone HB-B (550-0 cm)}

The sedimentary features in the tract $550-0 \mathrm{~cm}$ vary from reddish humified to little humified peat with brown peat material alternatively. The content of plant macroremains is dominated by Sphagnum magellanicum, while the concentration of vascular plants, as well as the concentration of Bryopsida, are very low compared to Zone HB-A. Remains of leafy liverworts and lichens (Cladonia sp.) were recognized only in the 
upper part of this zone. From 25-0 cm a strong decrease of Sphagnum magellanicum with lichens and increase in the concentration of liverworts.

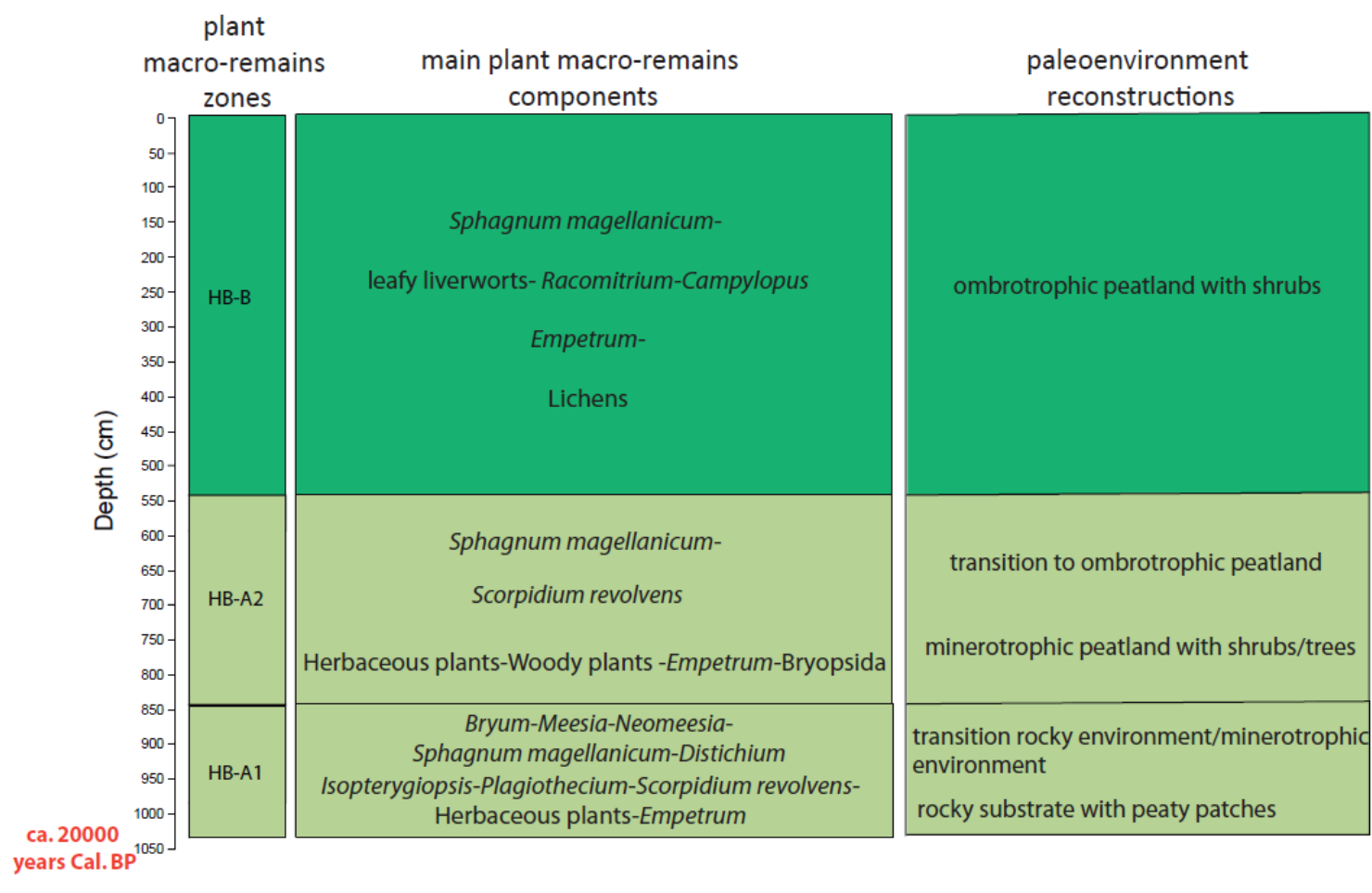

Fig. 6 Changes in plant macro-remains composition of $1035 \mathrm{~cm}$ Harberton peat-core, Tierra del Fuego. It is also detailed the paleoenvironmental reconstructions principally inferred from plant macro-remains content (modified from Savoretti 2018).

\section{Peat mining and commercial value}

Peat deposits from inner part of peatlands has been used since the XIIth century, as a low-calory fuel. From 1930 onwards first attempts for using peat with horticultural purposes, due to a set of physical and chemical properties which allow to develop a wide spectrum of growing media for intensive indoor cultures. The moss Sphagnum (with over 300 species at a global scale, according to Anderson et al. 2009) is at present one of the most appreciated for horticulture.

In the last two decades new peat-based applications have been developed, based on different types of mosses and including the live moss on the peatland surface. Some of them are solid base for leguminosae inoculants, industrial absorbents for oil and hydrocarbons, orchid intensive culture, mushroom casing, aquariums, biofertilizers, etc. 
Peat production in Tierra del Fuego started in 1970 and is regulated by the Minery Code (Código Minero) of Argentina. Local production is not enough to cover the national demand, this is why Argentina imports peatmoss from the North Hemisphere countries as Canada, Germany, Finland, Lituany, Estony, among others.

Before starting mining, peatlands must be drained to decrease the water level and allow low-weight machinery to enter the mine. Handy-scale mining peat is cut with shovels and is stored on outdoor "secaderos" (drying structures) in order to reduce its water content to $+/-30 \%$. Then the blocks are transported out of the peatland where it is milled and packed (Fig. 7). Most of Tierra del Fuego production is used within Argentina, which implies a high transportation cost to the main demand areas, at least $3,000 \mathrm{~km}$.

Peat production and import statistics, from 1999 to nowadays, show a progressing increase; it has been higher than 10,000 tons/year since 2004 , with a peak of 18,000 tons in 2017, out of which 12,000 tons were produced in Tierra del Fuego (Fig 8). In trade terms and considering the period 2007-2017, Argentina imported a total of peat for US\$ 16 million and purchases in the inner market for US\$ 20 million (Fig. 9).

Despite since 2011 Tierra del Fuego has implemented a strategy for the correct use of peatlands (Iturraspe 2016) it is necessary to elaborate conservation policies. This will be possible if studies on peatland restoration rate are carried out. By this reason the continuity of studies on the biodiversity of Tierra del Fuego peatlands is essential.

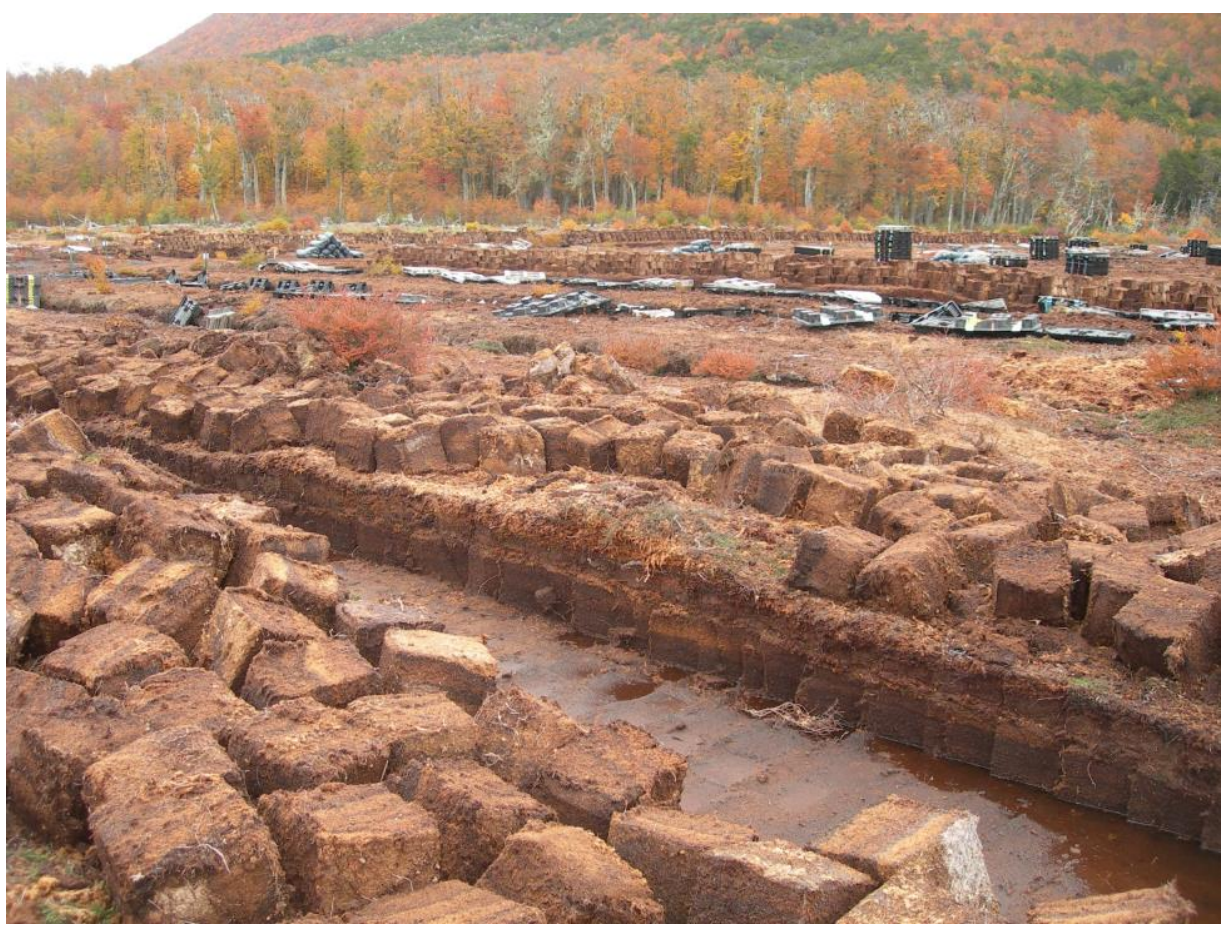


Fig. 7 Peat mining in a Sphagnum magellanicum bog from Tierra del Fuego. Peat is cut with shovels and is stored on "secaderos" in order to reduce its water content.

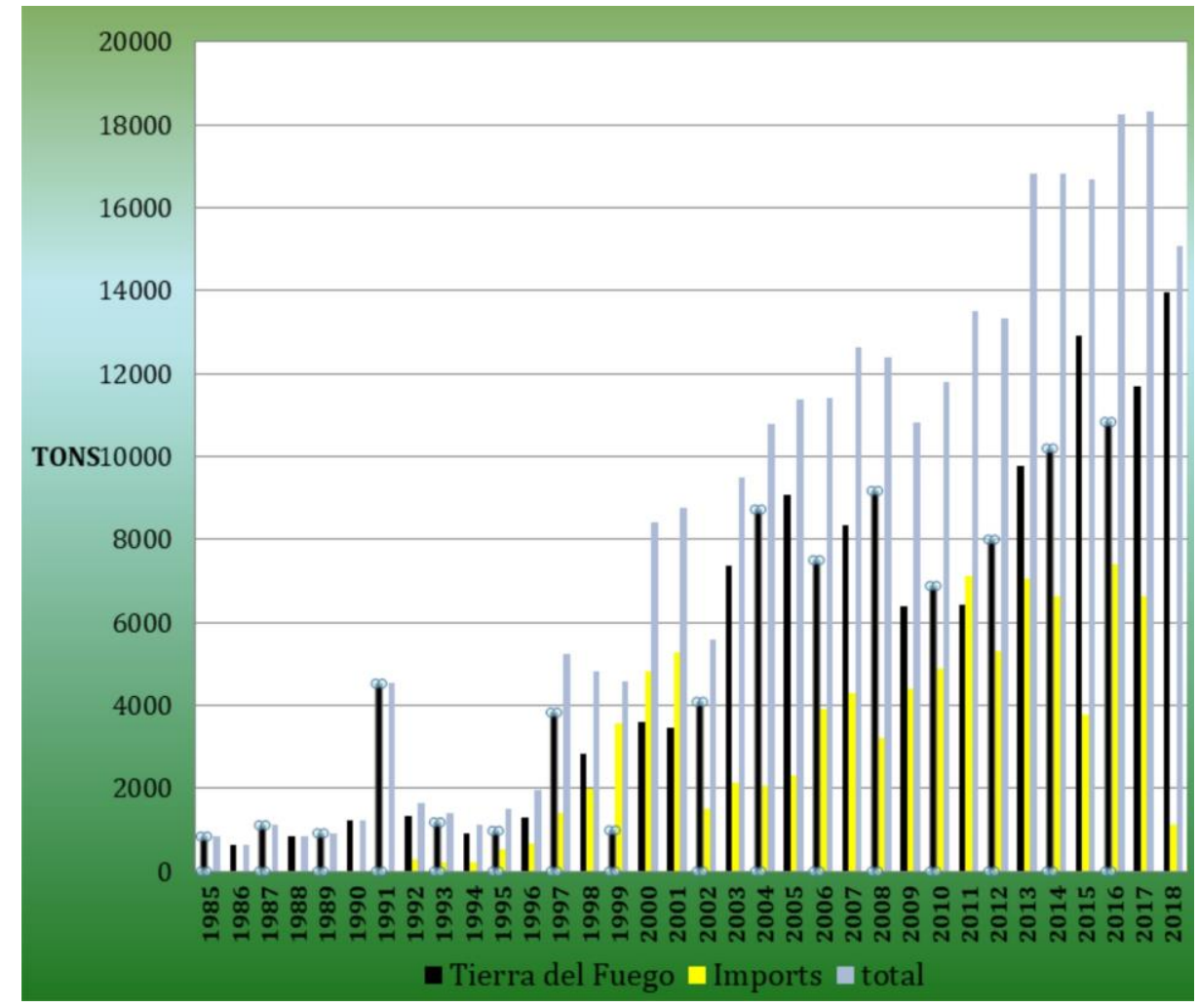

Fig. 8 Peat production in Tierra del Fuego and Argentine imports (tons). 


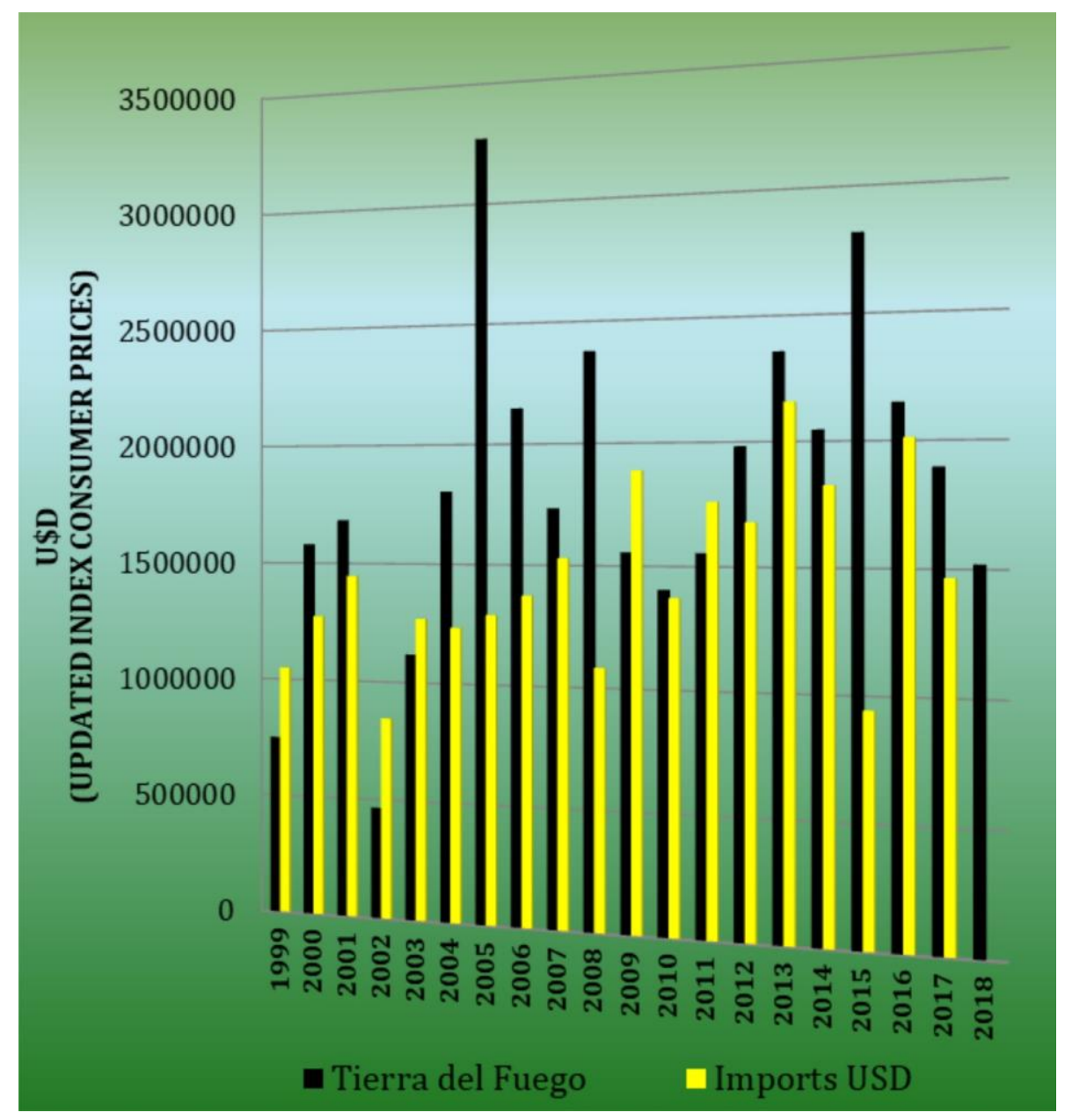

Fig 9 Peat production in Tierra del Fuego and Argentine imports (US\$).

\section{Final remarks}

Tierra del Fuego peatlands are unique environments because of their geographical location, floristic and hydrological features and ecosystem significance (Rabassa et al. 2006). Another important aspect refers to their continuous growth and accumulation pattern making possible paleoclimatic and paleoenvironmental reconstructions at regional and local scales base on different proxy records, e.g. palynolomorphs, plant macro-remains, diatoms, atmospheric dust (Rabassa et al. 2006, Ponce et al., 2014). Peatlands also have essential roles in the Carbone Cycle as natural methane sources (Münchberger et al. 2019) and as providers of freshwater, enhancers flood regulation capacity, improvers of water quality, and diminish soil erosion (Iturraspe 2016).

Great peatlands extensions and their unique physiognomy between all the other ecosystems make them an important tourism attractive; winter sports plus recreational activities on them produce economic profit in Tierra del Fuego (Iturraspe 2016). 
Environmental and hydrological peatland conditions provided by the dominant vegetation (e.g. Sphagnum magellanicum, Astelia pumila-Donatia fascicularis) allow the development of a notable diversity of organisms such as mosses, liverworts and lichens, and they, for example, play a key role in bird nesting. Despite most of the Tierra del Fuego peatlands are in pristine conditions, the environmental problems of them generally increase as the regional population increases (Iturraspe 2016). Giving people information about peatland origin, age of formation, types, biodiversity they hosted and their landscape values and functions is essential to make possible conservation actions in these particular environments.

\section{Acknowledgments}

The first author would like to thanks Juan Larraín (Pontificia Universidad Católica de Valparaíso), María Magdalena Schiavone and Guillermo Suárez (Facultad de Ciencias Naturales e Instituto Miguel Lillo) for their help in bryophytes assignation. Andrea Coronato wants to thanks to all the collaborators who joined the Laboratorio de Geomorfología y Geología del Cuaternario (CADIC-CONICET) group in Fuegian peatlands studies along the time. Part of this work was funded by Consejo Nacional de Investigaciones Científicos y Tecnológicas’ Fellowship to A Savoretti.

\section{References}

Amigo J, San Martín C, Ramírez C, Álvarez M (2017) Nomenclatural revision and syntaxonomical proposal for wetland peat vegetation in the Valdivian-Magellanian region. Lazaroa 38(2), 165-187.

Anderson LE, Shaw AJ, Shaw B (2009) Peat mosses of the Southeastern United States. Memoirs of The New Botanical Garden, vol 102. Buck WR (ed). New York. The New York Botanical Garden Press.

Auer V (1965) Pleistocene of Fuego Patagonia, IV: Bog Profiles. Annales Academiae Scientiarum Fennicae A III 80: 1-160.

Birks H H (2017) Plant Macrofossil Introduction, Reference Module in Earth Systems and Environmental Sciences, Elsevier. 
Bonarelli G (1917) Tierra del Fuego y sus turberas. Dirección Nacional de Minas y Geología. XII (3).

Borromei AM, Ponce JF, Coronato A, et al. (2014) Reconstrucción de la vegetación posglacial y su relación con el ascenso relativo del nivel del mar en el extremo Este del canal Beagle, Tierra del Fuego, Argentina. Andean geology 41(2): 362379.

Clymo RS (1984) Sphagnum-dominated peat bog: a naturally acid ecosystem. Philosophical Transactions of the Royal Society of London. B, Biological Sciences, 305(1124): 487-499.

Coronato A, Roig C, Collado L, Roig F (2006). Geomorphologic emplacement and vegetation characteristics of Fuegian peatlands, southernmost Argentina, South America. In: (Martini IP, Martinez Cortizas A, Chesworth W (eds) Peatlands: Evolution and Records of Environmental and Climate Changes, Development in Earth Surface Processes Series, 9, 111-129. Elsevier.

Dickson LA (1986) Bryophyte analysis. In: Handbook of Palaeoecology and Palaeohydrology. Berglund BE (ed), 627-643. Wiley. Chichester.

Echeverría ME (2016) Paleoecología de los Bosques de Nothofagus del sudoeste de Patagonia durante el Holoceno. Tesis doctoral. Facultad de Ciencias Exactas y Naturales, Universidad Nacional de Mar del Plata. Mar del Plata, Argentina. Inédito.

Heusser CJ (1995) Palaeoecology of a Donatia-Astelia cushion bog, Magellanic Moorland-Subantarctic evergreen forest transition, southern Tierra del Fuego, Argentina. Review of Palaeobotany and Palynology 89(3-4): 429-440.

Iturraspe R (2016) Patagonian Peatlands (Argentina and Chile) In: CM Finlayson et al. (eds) The Wetland Book: II: Distribution, Description and Conservation, 1-10. 
Janssens JA (1990) Methods in Quaternary Ecology 11. Bryophytes. Geoscience Canada 17: 13-23.

Kühnemann O (1976) Observaciones ecológicas sobre la vegetación marina y terrestre de la Isla de los Estados (Tierra del Fuego, Argentina). Ecosur, 3 (6): 121-248.

Loisel J and Yu Z (2013) Holocene peatland carbon dynamics in Patagonia. Quaternary Science Reviews, 69: 125-141.

Mauquoy D, Blaauw M, van Geel B, et al. (2004) Late Holocene climatic changes in Tierra del Fuego based on multiproxy analyses of peat deposits. Quaternary Research, 61: 148-158.

Mauquoy D, Hughes PDM, van Geel B (2010) A protocol for plant macrofossil analysis of peat deposits. Mires and Peat 7 (6): 1-5.

Mauquoy D and Van Geel B (2007) Plant macrofossil methods and studies: mire and peatmacros. In: Encyclopedia of quaternary science. Scott AE (ed) Amsterdam. Elsevier Science, 2315-2336.

Moore MD (1983) Flora of Tierra del Fuego. Antony Nelson (ed). St. Louis. Missouri Botanical Garden.

Münchberger W, Knorr K-H, Blodau C, Pancotto VA, Kleinebecker T (2019) Zero to moderate methane emissions in a densely rooted, pristine Patagonian bog biogeochemical controls as revealed from isotopic evidence. Biogeosciences 16: 541559.

Pisano E (1977) Fitogeografía de Fuego-Patagonia chilena I. Comunidades vegetales entre las latitudes $52^{\circ}$ y $56^{\circ} \mathrm{S}$. Anales del Instituto de la Patagonia, 8: 121-250, Punta Arenas (Chile).

Ponce JF, Coronato A, Fernández M, Rabassa JO, Roig C (2014) Las turberas de Tierra del Fuego y el clima del pasado. Asociación Civil Ciencia Hoy (ed). Ciencia Hoy 137: 11-17. 
Ponce JF, Rabassa J (2012) Geomorfología glacial de la Isla de los Estados, Tierra del Fuego, Argentina. Revista de la Sociedad Geológica de España 25,1-2: 67-84.

Rabassa J, Coronato A, Bujalesky G, et al. (2000) Quaternary of Tierra del Fuego, southernmost South America: an updated review. Quaternary International 68: 217-240.

Rabassa J, Coronato A, Heusser CJ et al. (2006) The peatlands of Argentine Tierra del Fuego as a source for paleoclimatic and paleoenvironmental information. In: Martini IP, Martinez Cortizas A, Chesworth W (eds) Peatlands: Evolution and Records of Environmental and Climate Changes. Development in Earth Surface Processes Series, 9, 129-145 Elsevier.

Rabassa J; Coronato A, Roig C (1996) The Peat-bogs of Tierra del Fuego, Argentina. In: Lappalainen, E. (ed) Global Peat Resources 261-266. International Peat Society Publisher.

Rabassa J, Serrat D, Martí Bono C and Coronato A (1990) Internal structure of drumlins in Gable Island, Beagle Channel, Tierra del Fuego, Argentina. LUNDQUA Report 32: 3-6, Lund, Suecia.

Roig, FA (1998) La vegetación de la Patagonia. In: Correa M N (ed) Flora Patagónica, parte 1, 48-166. Colección Científica del I.N.T.A. Tomo VIII. Buenos Aires.

Roig FA (2000) Comunidades vegetales productoras de turba en Tierra del Fuego. In: Curso-Taller de Conservación de Ecosistemas a nivel mundial con énfasis en las turberas de Tierra del Fuego. Coronato A and Roig C (eds). Ushuaia, Tierra del Fuego, $33-54$.

Roig CE, Roig FA, Carretero EM (2004) Tolhuin, provincia de Tierra del Fuego. In: Los turbales de Patagonia. Bases para su inventario y la conservación de su biodiversidad. Publicación 19. Blanco DE y de la Balze VM (eds). Países Bajos. Wetlands International. 
Roivainen H (1954) Studien über die Moore Feuerlands: 22 Tabellen im Text. Societas Zoologica Botanica Fennica" Vanamo".

Rydin H and Jeglum JK (2006) The Biology of Peatlands Oxford University Press. New York.

Savoretti A (2018) Estudio de las briofitas de turberas de Tierra del Fuego (Argentina) desde el último Máximo Glacial a la actualidad y su relación con las fluctuaciones climáticas y ambientales. Tesis Doctoral. Facultad de Ciencias Naturales y Museo, Universidad Nacional de La Plata. La Plata, Argentina. Inédito.

Van der Putten N, Mauquoy D, Verbruggen C, et al. (2012) Subantarctic peatlands and their potential as palaeoenvironmental and palaeoclimatic archives. Quaternary International 268: 65-76.

Vitt DH and Wieder RK (2009) The structure and function of bryophyte-dominated peatlands. In: Bryophyte Biology. Goffinet B and Shaw AJ (eds). Cambridge, Cambridge University Press. 357-391. 